\title{
The Unconquered Grounds: Christian Response to the Traditional Religious Discrimination against the Osu Caste in Igbo Land, Nigeria
}

\author{
Ernest O. Anyacho", ${ }^{1, *}$ Eunice I. Anyacho² \\ ${ }^{1}$ Department of Christian Religious Studies, Federal College of Education, Nigeria \\ ${ }^{2}$ Department of Igbo Language Culture, Federal College of Education, Nigeria
}

Copyright $\bigcirc 2016$ by authors, all rights reserved. Authors agree that this article remains permanently open access under the terms of the Creative Commons Attribution License 4.0 International License

\begin{abstract}
The traditional religion of the Igbo of Nigeria stratified the society into two major groups namely the Diala and the $O s u$. The former enjoys every right and privilege in the community while the latter has limited acceptance. There are also other areas of social inequality which the paper addresses as social stigmatization that make the so-called Osu second class citizens in Igbo land. All these are based on Igbo traditional religious beliefs and/or superstitions. The continued existence of these stigmatizations in the twenty-first century and in the land where Christianity has stayed for more than a century is a major of the study. The paper, therefore, investigates into different dimensions of the discrimination and inequality against the $O s u$ even after they have been converted to Christianity. It further looks at the reason why these have remained unconquered grounds when writers claim that Christianity conquered Igbo land many decades ago. The paper presents an ecumenical model that could be explored in handling the delicate issues so that conflicts could be avoided while trying to make the $O s u$ assert their full fundamental rights in Igbo land.
\end{abstract}

Keywords Osu-caste, Caste System, Social Discrimination, Fundamental Human Rights

\section{Introduction}

African culture was influenced by many change agents. These agents keep on changing both the material and non-material culture. The foremost change agents that impacted very much on African culture include colonization by the British and European masters, Christianity and western education. These factors according to O.U Kalu forced an irresistible western culture which affected the whole gamut of people's way of life namely their marriage, means of livelihood, religion and technology [1]. Christianity and western education brought by the European missionaries in the nineteenth century made more impacts on the Africans than any other agents of change. Through its teaching, majority of the people abandoned their traditional practices which were then seen and described as vestige of paganism and idolatry. That did not of course go without resistance by the adherents of Igbo traditional religion. The fight of Christianity against Igbo traditional religion, the resistance of the religion, her aspect of failures and areas of resilience as well as victory of Christianity were presented by some Igbo scholars in the book, The Gods in Retreat. One of the resilient areas of the religious beliefs and practice is the belief that some group of Igbo called the Osu (outcast) are not ritually clean and as such should not be accorded all the freedom and rights accorded to other Igbo. The Osu caste, therefore, has, in spite of the claim of victory of Christianity over Igbo religion and in spite of more than 80 per-cent of the Igbo that are Christians, remained an unconquered ground. The socio-political and psychological implications that this discrimination brings out in the modern times are of serious sociological concern hence the paper.

\section{The Igbos}

Igbo is one of the largest ethnic groups in Nigeria [2] The Igbo are found in south -eastern part of Nigeria. They are found in the five states that make up the South- eastern political zone of Nigeria namely Anambra, Imo, Abia Ebonyi and Enugu States. Few Igbo are also found in Delta and River States. Igbo is the name of the ethnic group as well as the name of the language of the people. Major occupations of the people include farming, trade and commerce and civil service. They are achievement oriented people who believe much in achieved status rather than ascribed. They are very adventurous- always exploring new opportunities for trade and commerce. They have fluid political organization where the family (nuclear and extended) plays very crucial roles in resource allocation. The Igbo has peculiar social and political organization which has been aptly described by Igbo scholars (Angulu 
Onwuejeogwu [3], F. C. Ogbalu [4], Ikenga-Metuh [5], O.U Kalu, [6]. Ikenga-Metuh remarks that Igbos live in a cephalous and organized societies. This explains the egalitarian outlook and the fiercely competitive spirit which characterize the Igbo. There is social mobility for there is no inherited aristocracy .Great emphasis is placed on self-made person and the way to prestige is open to all" [7] TU. Osuala also described the Igbo traditional social organization in the following words

One significant thing about the Igbo traditional societies is the absence of an all-embracing social and political system with the talk of the Igbo as a unit. Indeed one of the most striking features about the pre-colonial Igbo society was its apparent social fragmentation with hundreds of small, more or less independent social units ; the largest being , in many cases, what we call)the village group [8]

Kalu (online) classified Igbo political system into four major types:

(1) Those with a monarchical state system (Onitsha, Oguta, Nri, Osomari and Arochukwu); the king had a graded cabinet and often used a secret society as an executive arm. ${ }^{l}$ [ddd] Titled people (ozo) were not automatically advisers.

(2) Those in which the village chiefs ruled with titled people (nze or ozo/ichie) as advisers, often consulting the people and the women (umuada) and using some secret societies as enforcement agencies.

(3) Those in which the village chiefs ruled with representatives of family heads and members of a key secret society.

(4) Those in which the village chiefs ruled with representatives of the autochthonous families and with the oldest age grade. The next two age grades acted as the executive arm while the populace and women shared in decision making [9]

Igbos mostly practices exogamous marriage system. This, according to Green makes it possible for everyman to have relations with the birthplace of his mother, his wife with the various places into which his sisters (and from which his brothers) have married [10]. Thus Igbos are very particular in choosing families with whom they want to establish relationship and therefore consciously put in great effort to inquire about family lineage.

\section{Igbo Traditional Religion}

Like every African traditional religious attitude to life the Igbo fall into Mbiti's description who said:

"Africans are notoriously religious and each people has its own religious system with a set of beliefs and practices. Religion permeates into all the departments of life so fully that it is not easy or possible always to isolate it. ... Religion is the strongest element

\footnotetext{
${ }^{1}$ O. U Kalu. History of Christianity in West Africa, Longman, London,
} 1980 traditional background and exerts probably the greatest influence upon the thinking and living of the people concerned" [11]

Igbo traditional world-view which also defines her philosophy is located in the complex relationship between three-tier spheres namely sky (elu) earth (land) and the earth beyond (ala ттио). Sky is the abode of the supreme deity $(C h u k w u)$. Earth is the abode of human beings and gods who are superintendent of different aspects of human life like birth, agriculture, rain, health, protection and vengeance. The earth beneath is domiciled by ancestors (the dead fathers, mothers and relations). The supreme deity is approached by humans through the ministerial deities. Life on earth is also monitored and controlled by the ancestors who, according to Ernest Anyacho [12] and T. N. O Quacopoome [13] are described as the heroes and heroines, of the African nation who, though dead, are believed to be living and active in the affairs of their living community. Centrality of the earth in this complex relationship gave the earth goddess (Ala) a significant role as the next to Chukwu in terms of power and influence. It is god of morality, fertility, justice and equity. Land is, therefore, ritually treated as sacred and can be desecrated by any action that offends the earth goddess and/ or the ancestors. Such actions are defined in the numerous taboos that exist in Igbo land. These are prohibitions which control human action in relation to fellows and the environment. It is strongly believed that any person who contravenes any of the taboos will be punished by the deities and that an offence committed by a person is capable of dissipating unpalatable consequences on the living to the effect that mysterious death, natural disasters and calamities can be used by the supernatural forces to visit those in the community irrespective of who committed the taboo. One of such taboo is the $O s u$ caste taboo which prohibits marital and sexual relationship with any person from a family or group stigmatized $O s u$

\section{The Osu Caste System in Igbo}

Igbos have two classes of people, the Diala (free born) and Osu (cult slave) The Diala are the sons of the soil or as their name implies masters in the land. The $O s u$ are those who come from families dedicated to the gods of the land. They are regarded as slaves, strangers, outcasts, ritually unclean and therefore untouchable. What made them $O s u$ was either that their progenitor was sacrificed to a deity as a cult slave or being threatened with option of execution or sold to slave dealers by a unmerciful creditor their fore-fathers ran into a shrine of a deity for life-long refuge. To grant such refuge the priest of the shrine would either shoot a gun or beat metal gong (Igbugbo) four times in the presence of other witnesses [14]. It was one of these reasons that made the victim and his posterity enter into a special negative citizenship of the community. With this in place the whole family became out -caste. Initially the practice and treatment were very obnoxious and inhuman. Asinugo in the Nigerian Voice of twenty-seventh, August 2014 described the treatment against Osu succinctly 
The Osu were generally known as people who had been sacrificed to the gods of Igboland, descendants of people who were sacrificed to the gods hundreds of years ago. Such people and their families were shunned in the society, banished from communal land, banned from active participation in village life and refused the right to marry anyone who was from the family of a freeborn. They were banned from participating in any form of social activity. They had no land of their own. They lived in the shrine of the gods, or within market squares, and were forced to farm the land close to the road. The general belief was that they had been dedicated to the gods and that they belonged to the gods and not to the world of human beings. They were defined as a cult slave of the deities. They assisted the high priest of the traditional religion to serve the deities or the gods in their shrines. [15]

Based on this belief the Diala treat them as second class citizens and visibly discriminate against them in many ways.

\section{Traditional Kola Breaking and Libation Prayers}

Breaking of kola-nut is a cultural practice exclusively done by men. Women are not allowed to break kola nor say the kola prayer let alone pour libation. Diala will not eat kola broken by $\mathrm{Osu}$. Kola nut plays significant role in Igbo society. kola nut is at the centre of Igbo culture and theology and to deny a man of the right to break kola nut was tantamount to denying him the rights that made him a man. "So, it was an anomaly for a person to give kola nut to an $O s u$ either privately or in the presence of a visitor or even to show the kola nut to an $O s u$. An $O s u$ was forbidden from giving kola nut to a Diala who visits him." [16]

\section{Marriage and Sexual Relationship}

The discrimination against the $O s u$ in marital and sexual relationship appears to be worse than discrimination in other areas. Marriage of intending couples has been abruptly terminated by the simple reason that one of them came from the caste family. Adugani, Uzoaru and Obeta [17] reported the case of Emeka, a Spain based bachelor from Amichi town and Amarachi, a spinster from Igboukwu town all from Anambra State, Nigeria whose marital plan was shattered in 2012 by the refusal of Amarachi's family after finding out through investigation that Emeka is from Osu family. Amarachi's disappointment could be seen in her words

Because we loved each other and wanted the marriage to work out, we did everything possible. For instance, we visited a Rev Father in our village church and the traditional ruler of my village. Our Rev Father even advised us that the only way he could wed us in the church was for us to go to a court and pay the dowry there and then collect an evidence of payment that we are married. He said with that, he would have a reason to wed us. However, all the efforts we made did not yield any positive result, [18]
There have been several instances where some Igbo young men and women have suffered heartbreaks and emotional traumas as a result of this cultural disease.

\section{Titles, Honors and Social Recognitions}

Social recognitions in form of titles, honors and awards are given to illustrious sons and daughters as a way of acknowledging their outstanding contribution to the welfare of the society. There are also the traditional $\mathrm{OzO}$ and Nze title societies which wealthy individuals are initiated into. It is the highest social status an Igbo can attain in the communities where it operates. The highest traditional and political position is Eze or Igwe (title for village traditional ruler). No $o s u$ is allowed to become a member of any because of the stigma .Leo Igwe reported a case where a chief in Imo State was dethroned in 1997 because he was from Osu family.

"In 1997, a person alleged to be an Osu was made a chief in a community in Imo State. But six months later, the community was engulfed in a crisis. And when the case was brought to the court, the presiding judge noted that though the abolition of $O s u$ caste system was in the statute, it was an unenforceable law. The chief was dethroned so that peace would reign in the community". [19]

\section{Blood Transfusion}

Blood transfusion can be rejected by a Diala if he finds out it is donated by somebody from Osu family simply because of the belief that blood donated by an o

$O s u$ will contaminate a freeborn.

\section{Burial Rites and Restricted Residential Areas}

Some Igbo communities still do not allow Diala to bury an $O s u$. Burial is not just a simple affair which can be done at the wish of every family. Each community has rules governing where the grave will be dug, who will dig it and who will do the internment. A Diala is not permitted by native law to bury an $O s u$ and vice versa. In some communities, the Osus are limited to particular area where they can build their residential quarters. Diala do not easily sell land to them because that would mean giving them privilege to live closer to the freeborn thereby making a leeway for them to move out of the stigmatized zone.

Generally, treatments given to Osus are so bad that those innocently and accidentally born in the stigmatized families would not want their future generation to be born into family called Osu. Madugba reported the case of a brilliant professor who refused to marry till he died because of the discrimination he and his family suffered as a result of coming from a family tagged $O s u$. [20]

A Human Rights group cited in Igwe outlined the atrocities meted to the $O s u$ in Igboland. They include: parents administering poison to their children, disinheritance, ostracism, organized attack, heaping harvest offering separately in churches, denial of membership in social clubs, violent disruption of marriage ceremonies, denial of chieftaincy titles, deprivation of property and expulsion of wives etc.[21] 


\section{Why Osu-caste Remained Unconquered Ground}

Christianity through the church and her missionaries fought and conquered many practices based on superstitions and paganism. Killing of twins and "trial by ordeal" were stopped through missionary activities of Mary Slessor, a Scottish Presbyterian Missionary that worked in Eastern Nigeria region. Killing of children who cut the upper teeth was also stopped by Christianity. Many powerful idols like the Long Juju of Aro Chukwu was fought and won by the colonial masters. The powerful Mgbafor Ezira, the priestess of Onyirioha deity in Ezira, Anambra State was conquered and imprisoned by the joint effort of the church and colonial government in the 1920s. The Igo mma ogo institution (a practice whereby females deities marry human wives dedicated to Adoro female deity who are impregnated through anonymous human male sperm donors) in Ala-Unor village, Northern Igbo-land was fought and defeated by white missionaries[22]The big question now is the factor responsible for die-hardness of Osu-caste after other inhuman practices have been decisively fought.

$O s u$ has remained unconquered because of the failure of the Igbo to discontinue giving Ala (earth-goddess) the power ascribed to it in Igbo traditional religion. This is regarded by her worshippers as a powerful deity feared and worshipped in many parts of Igbo community. In many places in Igbo sub-culture area such as Central Igbo and North-western Igbo areas Ala is the owner of Osu hence they are called $O s u$ aja ala (Osu owned by Ala).Describing the deity N.S.S Iwe says

Ala (Ani or Ana): This is the most common divinity in Igboland. It is therefore generally the arch-divinity of every locality. It is regarded as the earth goddess of fertility and the custodian of public morality in co-operation with the spirit of our departed and venerable ancestors... Breaches of public morality or social prohibitions and taboos (nso ala). Such as stealing from the barn, homicide, incest, infidelity, etc. are all considered offences against the community (Ala)... Emphasizing the pre-eminence of Ala among the other divinities. Echeruo remarks:"One divinity, however, was beyond the capriciousness of Igbo men: that divinity is neither Igwe, nor even Chukwu, but A la, the goddess of the earth. She was the one deity which no man or woman and no community could afford to offend, much less discard. '[23]

Thus, many Igbo Christian, irrespective of claims of conversion still respect this deity, participate in her annual festival, play masquerade ( which are symbols of the ancestors ) in respect of Ala (earth-goddess) They still observe her dos and don'ts and seriously hold tenaciously to omenala (tradition as prescribed by the land). Most of the omenala are founded on respect to the traditional religion which is seriously dominated by worship and reverence of Ala (earth-goddess).This is accompanied by series of taboos which spell out prohibitive acts. These taboos are called nsoala (what the land prohibits) or aru (abominations).
Contravention against any of the taboos is interpreted as abomination, a serious affront to the earth-goddess. Marriage of $O s u$, sexual relationship with an osu and shedding the blood of an osu are abominations (aru) forbidden by the earth-goddess. Nobody would want to break her prohibition for fear of unpleasant consequences .Therefore, it is this strong hold of the Igbo traditional religion on the people that still sustains the osu-caste system .The above fear is not much of what the earth-goddess, left alone will do but more of the punishment many in the community, majority being Christians will do to them by ostracizing them, disowning, denying the inheritance right and dragging their name into the osu-caste. This is the crux of the matter. It is easy to break the osu jinx if only Igbo Christians in each community will have unanimous voice against it as a vestige of traditional religion and a mark of its supremacy in marriage and social relationship among the Igbo of south-eastern Nigeria.

\section{Ecumenical Approach}

Presented in the sense of unity among the Christian bodies in terms of understanding tolerance and joint effort in defending the Christian faith and living harmoniously with other faith, ecumenical dialogue has been a recommendable approach in handling critical issues to the body of Christ.

Ecumenical dialogues are talks and discussions between two or more churches aimed at overcoming the inherited divergences/differences, often doctrinal and church order and principles that separate them. Such dialogue becomes very necessary when a particular social problem affects people irrespective of their denominational affiliation. Osu caste-system is a religious practice arising from Igbo traditional religious beliefs It is a traditional theological issue which affects Christians who (by conversion) should no longer suffer dehumanizing practices of former religion of their forebears. Thus issues that affect members of the community, irrespective of their religious faith, require efforts from all the churches. Osu caste system does not respect any religion. Christians, Moslems, African traditional religious adherents and faithful of other religions suffer the same discrimination and limitations that osu-caste system places directly on the $O s u$ family and indirectly on non-Osu who want to marry or get into closer political, social and economic relation with a person from $O s u$ family. A church which wants to fight it alone would not have complete victory because different stands people take with respect to stopping the caste-system. Some Christians feel that it is a cultural matter; as such the church should not dabble into it. Another group believes that it should be left to time believing that with the influence of modernity, urbanization and civilization it will die naturally. Another group believes that the practice should be stopped now through legislation, public enlightenment and church intervention. Some churches have gone ahead to ordain some men from "osu families." Though their ordination has enhanced their religious status yet the stigma still remains. 
We therefore recommend ecumenical/ inter-religious dialogue as a principle for fighting the caste system. This involves calling a meeting of all the religious leaders, all the traditional rulers (the Ezes, Igwes), the Ohaneze (pan Igbo social and political organization), the opinion leaders and leaders of thought in Igbo land, the title societies (the $\mathrm{Nze}$ and $\mathrm{Ozo}$ ), Igbo intellectuals and the legislators from the Houses of Assembly of the five South-eastern States of Nigeria that make up Igbo-land. Many in these groups are custodians of tradition and powerful voices that can be listened to by all.

Ecumenical dialogue would make the Christians stand with a common understanding and voice while interreligious dialogue would bring all the faiths together for dialogue over a common cultural and religious practice that constitute social ,political, psychological, economic and human rights problem for centuries now. The ecumenical / inter -religious dialogue approach enunciated in this paper would include calling back past efforts made at fighting osu and merging them with present efforts as well as bringing all stake-holders to a dialogue.

Past legislative efforts at fighting Osu-caste system should as a matter of urgency be re-visited. The defunct Eastern Nigeria of House Assembly debated against osu-caste system in 1956. The house proceedings of March 20, 1956 on the passage of the Bill cited in Igwe and Akolokwu state:

...it is devilish and most uncharitable to brand any human being with a label of inferiority, due to the accidents of history", while seconding the motion for the second reading of the abolition of the Osu caste system, he said: The objects and reasons for the bill are humanitarian and altruistic. The bill seeks to abolish the Osu system and its allied practices including the Oru, or Ohu system; to prescribe punishment for their continued practice, and to remove certain social disabilities caused by the enforcement of the Osu and its allied system. I will not join in the encouragement of a system of society where one stratum can superciliously claim to be descended from the best brain and would therefore consign the others to a scrap heap of their own invention and ostracise them socially [24]

Another effort was when the Nigerian Peoples Party (NPP) Government in Imo State led by the then governor, Sam Mbakwe condemned $O s u$ practice. The then military Administrator, late Air Commodore Emeka Omerua of the old Anambra State moved against the Efuru deities in Ukehe, Igbo-Etiti Local Government Area, destroying the shrines with bulldozer because of similar case of cult slavery [25].These laws and actions of former Igbo leaders should be used to build strong support for the fight against osu caste system in Igbo-land.

Investigations show that the Catholic Archbishop of Owerri Ecclesiastical Province, Anthony J. V Obinna, has, in addition to his personal war against $O s u$ caste system urged teachers and students in mission schools to join the fight against Osu / Diala discrimination in Igbo land [26]. The work of Committee on the Elimination of Racial Discrimination (CERD) which compiled areas of discrimination against the $O s u$ is complimentary to the call for fight against $o s u$ system in Igbo-land [27]

The 1999 Constitution of Federal Republic of Nigeria has specific section on discrimination. Section 42(1) of the 1999 Constitution of Nigeria states inter-alia:

1. A citizen of Nigeria of a particular community, ethnic group, place of origin, sex, religion, or political opinion, shall not, by reason only that he is such a person:

(a) be subjected either expressly by, or in the practical application of any law in force in Nigeria or any executive or administrative action of the government, to disabilities or restrictions to which citizens of Nigeria of other communities, ethnic groups, place of origin, sex, religion, or political opinion are not made subject, or

(b) be accorded either expressly by, or in the practical application of any law in force in Nigeria or any such executive or administrative action, any privilege or advantage that is not accorded to citizens of Nigeria or other communities, ethnic group, place of origin, sex or political opinion.

2. No citizen of Nigeria shall be subjected to any disability or deprivation merely by reason of the circumstances of his birth. [28]

It is only through ecumenical approach that all legal and religious, constitutional and human instruments can be harnessed for effective fight against the unconquered ground. This approach is supported by the Igbo saying, "it is only combined effort that stops a stubborn evil from continuous existence".

\section{Conclusions}

A stranger may not fully appreciate the degree of discrimination, stigmatization and inequality the $O s u$ in Igboland, south-east of Nigeria face. Any belief and practice that make a twenty-first century person suffer social inequality and loss fundamental human rights should be jointly fought. Osu caste system, therefore, calls for concerted effort -local, national and international, religious and secular authorities to intervene so that this stigma will be fought and won. It may be noted that all the fight and conflict which the $O s u$ have staged against their plight have all been suppressed. Dike reported a case in 1989 when the Osu in Umuaka town, Imo State purposefully assaulted some Diala women sexually so that they could experience the pain of stigmatization. The trouble that came out of it did not abolish its practice in that town. Another protest by Umuode community in Enugu State in the 1990s and about 60 other similar protests by $O s u$ in Imo State reported by Dike [29] did not yield positive result. Failure of these individual efforts at fighting $o s u$ will convince every person on the need 
for joint effort in the fight against this social evil

\section{REFERENCES}

[1] O. U Kalu. History of Christianity in West Africa, Longman, London, 1980.

[2] T Uzodimma Nwala. Igbo philosophy. Heinemann, Ibadan, Nigeria, 1985 p. 1.

[3] M. Angulu Onwuejeogwu. The. Social Anthropology of Africa: An introduction, Heinemann Educational books, Ibadan, Nigeria, 1992.

[4] F.C Ogbalu. Omenala Igbo: The book of Igbo Customs, University Publishing company, 2006.

[5] Emefie Ikenga-Metuh. African Religion in Western Conceptual Scheme: Problem of Interpretation, Imico Press, Jos, Nigeria. Imico Press, 1991 p.3.

[6] O. U Kalu. Under the Eyes of the Gods: Sacralization and Control of Social Order in Igbo land. Online available from http//Ahajioku.igbonet.com/1988/.

[7] Ikenga-Metuh, p. 3.

[8] Osuala, p 17.

[9] Kalu, on-line.

[10] M.M Green. The Village Affair, Frank Cass, London, 1964.p.5.

[11] John S Mbiti. African Traditional Religion. Longmann, London, 1970, p. 1.

[12] Ernest Anyacho. Essential Themes in the Study of Religion. Nigerlink publishers, 2005, p. 251.

[13] T.N. OQuacopoome West African Traditional Religion. African University Press, 1987, Ibadan. p. 43.

[14] Ogbalu, 2006 p. 101.

[15] E Asinugo. The church and Fight Against Osu-caste System in Eastern Nigeria" Nigerian voice $27^{\text {th }}$ Augustatern - nigeria. htmls. Online available from http//:www.nigerianvoice.com. news16135/the-church-and-the-fight-against-osu-caste-syste m-in-e.

[16] E. Asinugo. Online $\backslash$.

[17] Asinugo, online.

[18] D, Adugo-Ani, S. Uzoaru and O .Obeta. Osu-caste-system: How it Affects Marriage in the S/East .Online available from http://leadership.ng.features/388826/osu-caste-system-affect s marriage.

[19] Leo Igwe. Osu caste-system, Online available from http//.www.muktomna.Article/Leo-igwe/osu-caste system.

[20] Madugba. "The Osu-caste System in Igbo-land: a Challenge to Igbo Christian Intellectual“. Trumpeta, April23, 2014.Online available fromwww.imotrumpeta.com/11713/.

[21] Leo Igwe. Osu Caste -system. Online available from http//:www.muktomna.Article/Leo-igwe-osu-caste-system.

[22] N. Achebe. Igo Mmo Ogo: The Adoro Deity, her wives and challengers -influences of reconstruction of Alo Unor Northern Igbo land 1890-1994, Online available from.https://eccentricyoruba.word.press/2012/11/18.pre-colo nial-igboland-marriage-to-a-god.

[23] N. S. S. Iwe .Igbo deities, 1998 Ahajioku Lecture, Online available fromhttp://ahajioku.igbonet.com/1998/.

[24] O. W. Igwe and G. W, Akaloku. The Scar that has Resisted Erassal: The D is crimination of Osu of Igbo land, Nigeria, Assessing Implications for Human Rights. American International Journal of Contemporary research Vol. 4 No 1, $277-285,2014$

[25] ibid.

[26] Madugba. The Osu Caste in Igbohttp://theleadreassumpta.co $\mathrm{m} / 2015 / 02 / 21$ owerri-education-week-teachers-urged-to-join -fight-against-osu-diala-discrimination.

[27] Committee on Elimination of Racial Discrimination (CERD).Thematic Discussion on the Osu- caste S ystem in Nigeria, Online available from. www.dalitfreedom.org.

[28] The Federal Republic of Nigeria. The 1999 Constitution of the Federal Republic of Nigeria. Government Press. Abuja, 1999.

[29] V. Dike. Osu caste system in Igbo land,. Online available fro $\mathrm{m}$. http://www.nigerianvillagesquare.com/index?php?option= content\&view=article. 